\title{
THE RED CROSS AND YOUTH
}

The review La Croix-Rouge suisse (Berne, 1975, No. 1) has published an article by Mr. James Christe, a former teacher who is now director of Red Cross Youth in French-speaking Switzerland. Under the title "Revolution? Evolution!", the writer refers to problems that arise in many countries, and we think it interesting to reproduce some excerpts from the article:

In Switzerland, as in fact in many other countries, youth organizations are as numerous as they are varied; yet all over Europe we see that structuralized youth movements attached to an organization no longer meet with as much success as in past years. Undoubtedly one of the reasons is that the young have many more interests in life. When one has an opportunity of hearing them, however, and to hear them one must take the trouble of listening, one realizes that to do something and to be able to express themselves is still one of their major concerns. And they must be convinced that what they are asked to do is really useful.

Even with the constant evolution of the society in which we live, even with ever greater industrialization and a steadily rising living standard, communities still have big tasks to fulfil. The young are always ready to render aid, but they prefer to do it in a less rigid setting. They no longer want to be part of an organization, as card-carrying members. What does interest them then? Their pals for one thing, and they are also interested in the programmes put forward. If both are to their liking, they will participate. Then they will be off. And what will they do next? It may be something different, and not necessarily in the same organization. In a number of cases they will do nothing else. It is important that the Red Cross should take the aspiration of the young into account so that it may devise a policy for youth. In this context, it is interesting to consider some of the motivations of the young. They agree to cooperate in proportion to what we are able to propose. Although wary of pure eloquence, they want to lead a more natural life. They crave 
autonomy, responsibility, authenticity and justice, and it is understandable that they should favour a certain concept of life based on factors that greatly differ from those which the present-day consumer society seeks to impose on them. They realize that practical action is possible only if undertaken by a group led by a chief chosen by themselves. While they are anxious to share responsibilities, those responsibilities can be exercised only if adults agree to trust them. Yet how many youth associations (generally serving educational purposes) have been devised by adults with programmes mainly directed at what they have considered necessary for the young ?...

As we all know, far-reaching studies are being conducted on the future of the Red Cross, at both international and Swiss levels. Successive periods do not resemble each other, as each has its own customs and usage. Ten years ago there was talk of how to occupy one's leisure or relax. Today we hear of involvement, joint administration and working in concert. Youth, in particular, lead a full life and intensely participate in the changes of the day. Now they demand to be heard and to take part in major decisions. They are ready to assert their demand-and we know at what price sometimes-for their rightful place in society.

And what about our society? Is the Red Cross aware of this phenomenon? Is it ready for that evolution within its organizations? How many sections are prepared to invite the young to take part in their activities?

The International Conference of the Red Cross has for a long time expressed the wish that the young should be an integral part of the Red Cross, that they be allowed to state their views and opinions, and that decisions be reached with them, particularly with regard to future policy. Tomorrow, those young people, who will have become adults, will be in control of the Red Cross. It is therefore essential that they should already feel responsible. The subjects in which it is proposed to interest the young are not lacking. It is simply a matter of wanting and finding a way to do so, and carrying it out to the end. The Youth programme is now being developed in some 110 Red Cross, Red Crescent and Red Lion and Sun Societies. A brief world survey shows us that there have been some interesting ventures and that they have often been successful.

Here a remark must first be made: most National Societies have a school youth programme which is often developed in close co-operation with the Ministry of Health and the Ministry of Education.

While the Red Cross Youth programme in some countries is solely geared to school, many Societies are striving to achieve a certain balance between school and extra-curricular activities which would extend to youths up to the age of twenty-five. 
In Thailand, for instance, the programme essentially developed in schools has an interesting feature. Two basic organizations are officially recognized at school, which is compulsory: the Red Cross and the Boy Scout movement, although the former is reserved for girls and the latter for boys.

In Tanzania, young people have asked the Red Cross to train them for hospital work, a sector which is short of qualified personnel. Aid to the handicapped aged is one of the major concerns of the British Red Cross. In this sector there is no room for improvisation. Hence the training courses which have been organized for young people interested in such activities.

The same applies to the USA and the Netherlands. In the latter country, for example, sport activities for the handicapped, from the age of five to thirty-five, are the responsibility of Red Cross youth groups.

In Lebanon, young people visit prisons and help those released to find work and resume contact with society. The same purpose has prompted some Swedish Red Cross Youth groups to set up a programme for prisoners.

As youth's place in society becomes more important, its role in the Red Cross must follow the same trend. The duties of the Red Cross towards the young may be summed up in three words: information, training and participation. The latter term calls for some elementary consideration. For more than fifty years, Red Cross Youth has been concerned about what it could do for the young. Now we should ask ourselves and ask the young what they can do for the Red Cross. This is not revolution but evolution. At a time when the Red Cross world is asking itself questions, we must know whether the past is to be reclaimed or the future built. 